\title{
A atuação do Poder Judiciário frente à responsabilidade civil do Estado pela ineficiência de fiscalização como instrumento de efetividade para se alcançar a proteção ambiental
}

\section{THE ROLE OF THE JUDICIARY FRONT OF LIABILITY OF THE STATE, BY INEFFICIENCY SURVEILLANCE AS EFFECTIVE TOOL FOR ACHIEVING ENVIRONMENTAL PROTECTION}

\author{
* Beatriz Souza Costa \\ ** Lívia Maria Cruz Gonçalves Souza
}

* Mestre e Doutora pela UFMG em Direito Constitucional. Professora no Curso de Mestrado em Direito Ambiental e Desenvolvimento Sustentável da Escola Superior Dom Helder Câmara. Próreitora de Pesquisa da ESDHC (Belo Horizonte). E-mail: biaambiental@ yahoo.com.br

** Mestranda em Direito Ambiental e Desenvolvimento Sustentável pela Escola Superior Dom Helder Câmara - ESDHC (Belo Horizonte). Advogada. email: liviamaria_cg@ hotmail.com
Resumo: O trabalho objetiva analisar o acórdão referente ao Recurso Especial n ${ }^{\circ} 647.493$ de 2007, julgado pelo Superior Tribunal de Justiça em razão de uma Ação Civil Pública ajuizada pelo Ministério Público do Estado de Santa Catarina, pelo dano ambiental decorrente da extração de Carvão na Região de Criciúma. Como resultado, a decisão considerou a Responsabilidade Civil subjetiva da União, pela falta de fiscalização na atividade extrativista de carvão minerário. Além disso, procura-se demonstrar que já existia legislação pertinente à época, e que a União continuou inerte em seu dever de agir. Por outro lado, aponta as consequências ambientais em virtude de tal atividade, assim como a importância da intervenção Judicial consciente para efetivar a proteção do meio ambiente.

Palavras-chave: Poder Judiciário; Intervenção; Proteção ambiental; Efetividade.

Abstract: The paper aims to analyze the judgment relating to the Special Appeal 647.493/ 2007, dismissed by the Superior Court on the grounds of a public civil action filed by the Prosecutor of the State of Santa Catarina, the environmental damage caused by the extraction of coal in the region of Criciúma. As a result, the decision considered the subjective Liability Union, the lack of oversight in the mining of coal mining activity. Also seeks to demonstrate that relevant legislation already existed at the time, and that the Union remained inert in his duty to act. On the other hand, points out the environmental consequences of such activity, and seeks to highlight the importance of conscious judicial intervention to enforce the protection of the environment.

Keywords: Judiciary; Intervention; Environmental protection; Effectiveness. 


\section{INTRODUÇÃO}

A proteção ambiental, cada vez mais, vem sendo discutida no contexto nacional e internacional, isto é fato. A ação antrópica tem contribuído para este debate, uma vez que, é notoriamente a maior causa de degradação ambiental.

Nesse sentido, faz-se necessário averiguar, a atuação do Estado diante de tais ações humanas, não somente como ente regulador e regulamentador, mas principalmente fiscalizador.

Diante desse contexto, o trabalho abarca a problemática sobre a existência de efetividade na aplicação da Responsabilidade Civil do Estado, diante de sua omissão, ou seja, na ausência de fiscalização.

Ao que tudo indica o Estado por si só, não exercerá uma fiscalização com afinco quando a degradação ambiental for proveniente de sua inércia. Prova disso é o próprio descumprimento da lei 6.938/81, pelo ente federado, dificultando a efetividade de uma política ambiental eficiente.

Tal premissa se justifica diante da necessidade de intervenção judicial para que as medidas sejam concretamente cumpridas, e o bem difuso protegido.

O objetivo deste trabalho é analisar o caso da poluição ambiental no Estado de Santa Catarina, especificamente na cidade de Criciúma, pela extração de carvão. O objeto de exame é o Recurso Especial nº 647.493 de 2007, julgado pelo Superior Tribunal de Justiça (STJ), que condena a União e as mineradoras solidariamente quanto ao dever de reparação e indenização por dano ambiental na região.

A análise se limitará a responsabilidade da União, não adentrando à responsabilidade das mineradoras.

Buscar-se-á demonstrar, que no caso em tela, a União manteve-se inerte diante da degradação ambiental, uma vez que, não fiscalizou a atuação das empresas extrativistas, justificando portanto a responsabilização.

Além disso, o estudo apanhará elementos que demonstrem que sem a intervenção judicial, principalmente no tocante à reparação do dano ambiental, a responsabilidade civil não seria tão efetiva.

Nesse sentido, levantará a importância da aplicação do instituto da Responsabilidade Civil ao próprio ente gestor, para que, se alcance maior eficiência e efetividade no exercício da Administração pública.

Do mesmo modo, averiguar-se-á que mesmo com a atuação judicial, a proteção ambiental pode ficar comprometida caso o órgão julgador não conheça os fundamentos jurídicos de forma profunda e sistemática. Assim como poderá 
o meio ambiente ficar prejudicado, se a sentença não estabelecer metas eficientes para que a responsabilidade tenha consequências efetivas.

\section{ESBOÇO DO CASO}

Trata-se, de um Recurso Especial decorrente de uma Ação Civil ajuizada pelo Ministério Público federal em 1993 contra a União, Estado de Santa Catarina e empresas carboníferas da região, em razão da degradação ambiental proveniente da extração do carvão vegetal.

No pedido do Ministério Público Federal, constava não só a elaboração de projeto para recuperação da área, como também indenização da população dos municípios onde as mineradoras se localizavam, além de cominações pecuniárias.

Sete anos depois, veio a sentença prolatada pelo Juiz Federal Paulo Afonso Brum Vaz condenando solidariamente os réus a recuperação do passivo ambiental. ${ }^{1}$

Esse ato jurisdicional foi alvo do inconformismo de quase todos os réus, que buscaram a via recursal até o cabimento do referido Recurso Especial.

Isto porque, o juiz ao julgar parcialmente procedente o pedido, estipulou multa de $1 \%$ sobre o valor da causa, em caso de atraso. Além de determinar, o ajustamento de conduta das mineradoras dentro de 60 dias com risco de interdição da atividade.

O Relator do Recurso Especial, o Exmo. Ministro João Otávio de Noronha proferiu voto em consonância com grande parte da sentença de primeiro grau.

Esse caso foi marcado não só pela extensão da área degradada que representava mais de 6.000 hectares, como também, pelo fato de ter reconhecido a responsabilidade da União pelo dano ocorrido, por ficar inerte quando deveria ter agido.

Bom frisar que a degradação ambiental foi tão grande que a área em comento foi concebida como Área Crítica Nacional pelo Decreto 85.206/80².

\footnotetext{
1 julgo procedente pedido principal para condenar os réus a apresentar dentro de seis meses cronograma mensal de etapas a serem executadas e executa um projeto de recuperação no prazo de 3 anos, da região que compõe a Bacia Carbonífera do Sul do Estado" contemplando "as áreas de depósitos de rejeitos, áreas mineradas a céu aberto e minas abandonadas, bem como o desassoreamento, fixação de barrancas, descontaminação e retificação dos cursos d'água, além de outras obras que visem amenizar os danos sofridos principalmente pela população dos municípios-sede da extração e do beneficiamento (VAZ, 2000)

2 Art. $1^{\circ}$. É acrescentado, ao artigo $8^{\circ}$ do Decreto $n^{\circ} 76.389$, de 3 de outubro de 1975 , o seguinte Inciso: "XIV - Região Sul do Estado de Santa Catarina."
} 
Nesse sentido, art. 8 do Decreto 76.389/75, já apontava, quais eram as áreas críticas até então consideradas no Brasil ${ }^{3}$.

Necessário se faz lembrar, que no mesmo ano do decreto, a lei 1.413 de 1975, já previa a importância de se proteger o meio ambiente, quanto à instalação de empreendimento industrial, de forma que havia determinação estabelecendo que nas áreas críticas deveria existir zoneamento urbano e instalação de equipamentos voltados para controle e poluição ${ }^{4}$.

Sendo assim, percebe-se que o não fazer da União não se justificava uma vez que já existia uma legislação preventiva, embora tênue, do dano ambiental.

Segundo o relatório apresentado no processo, os problemas enfrentados pela cidade de Criciúma em decorrência da atividade carvoeira foram muitos. Dentre eles, pode-se citar: assoreamento, comprometimento de 2/3 da malha hidrográfica, acidez da água dos rios, comprometimento da atividade pesqueira e abastecimento da cidade, comprometimento do solo e da vegetação. Além de colocar em cheque, a saúde e a qualidade de vida das populações locais.

A partir disso, o ministro iniciou seu voto, analisando o pedido recursal da União, que entre outras coisas, alegou que não tinha responsabilidade solidária com as empresas mineradoras, pois estas eram as poluidoras de fato, segundo

\footnotetext{
${ }^{3}$ Art. $8^{\circ}$. Para efeito dos artigos $3^{\circ}$ e $4^{\circ}$ do Decreto-lei $n^{\circ} 1.413$, de 14 de agosto de 1975 , são consideradas áreas críticas de poluição as relacionadas pelo II PND, a saber:

I - Região Metropolitana de São Paulo;

II - Região Metropolitana do Rio de Janeiro;

III - Região Metropolitana de Belo Horizonte;

IV - Região Metropolitana de Recife;

V - Região Metropolitana da Salvador;

VI - Região Metropolitana de Porto Alegre;

VII - Região Metropolitana de Curitiba;

VIII - Região de Cubatão;

IX - Região de Volta Redonda;

X - Bacia Hidrográfica do Médio e Baixo Tietê;

XI - Bacia Hidrográfica do Paraíba do Sul;

XII - Bacia Hidrográfica do Rio Jacuí e estuário do Gaiba;

XIII - Bacias Hidrográficas de Pernambuco.

4 Art. $3^{\circ}$ Dentro de uma política preventiva, os órgãos gestores de incentivos governamentais considerarão sempre a necessidade de não agravar a situação de áreas já críticas, nas decisões sobre localização industrial.

Art. $4^{\circ}$ Nas áreas críticas, será adotado esquema de zoneamento urbano, objetivando, inclusive, para as situações existentes, viabilizar alternativa adequada de nova localização, nos casos mais graves, assim como, em geral, estabelecer prazos razoáveis para a instalação dos equipamentos de controle da poluição.

Parágrafo único. Para efeito dos ajustamentos necessários, dar-se-á apoio de Governo, nos diferentes níveis, inclusive por financiamento especial para aquisição de dispositivos de controle.
} 
o princípio do poluidor pagador. Portanto, cabia a elas a reparação e indenização, caso contrário a sociedade estaria se auto-indenizando.

O tribunal, no entanto, considerou a responsabilidade subjetiva da União por faltar com o dever de fiscalizar, permitindo que a atividade minerária continuasse sem controle algum.

Esse posicionamento, foi fundamentado no Decreto-Lei $n^{\circ}$ 227/67 artigos $1^{\circ}, 3^{\circ}$ e 47 ; lei 7.805 de 1989 artigos $3^{\circ}, 9^{\circ}, 15,18$ e 19 além do Artigo 225 parágrafo $1^{\circ}, 2^{\circ}$ e $3^{\circ}$ da Constituição da República de 1988.

No que diz respeito à indenização, o acórdão aponta que, a União no exercício da "Governança ambiental", deve buscar a manutenção de um ambiente equilibrado. Para tanto deveria seguir as legislações supracitadas que dão subsídios para a intervenção Estatal, como por exemplo: o licenciamento, o Estudo de Impacto Ambiental, a multa, a advertência, a caducidade da concessão da lavra e até mesmo a suspensão da atividade.

Portanto, justifica-se o dever de indenizar, uma vez que, a União faltou com poder-dever-de-polícia ambiental, quando deveria fiscalizar, preservar e restaurar o meio ambiente e não o fez.

\section{CARVÃO E DANO AMBIENTAL, ASPECTOS CIENTÍFICOS}

O carvão é um recurso natural não renovável energético, muito utilizado para gerar eletricidade. É um dos minerais mais abundantes do planeta, segundo o Ministério do Meio Ambiente, só na região sul do Brasil, como Santa Catarina as reservas estão estimadas em 1,4 bilhões de toneladas contra 5,3 bilhões do Rio Grande Sul.

No mundo, as reservas maiores são divididas entre Estados Unidos, China e Rússia. As duas primeiras com quantidade suficiente para durar mais de 300 anos, conforme o consumo atual. (MILLER, 2013)

Esse combustível fóssil é formado por um processo geológico que ocorre por centenas de anos, decorrente da reação dos resíduos de plantas submetidos a calor e pressão. (MILLER, 2013)

Entender a composição desse recurso natural é importante para conhecer os efeitos da sua combustão. Assim sendo, ele possui, entre outros, dois elementos relevantes para o aquecimento global, quais sejam o carbono e o enxofre.

Quando o carvão é queimado para gerar energia, liberam gases de efeito estufa como o dióxido de carbono $\left(\mathrm{CO}_{2}\right)$, óxido de enxofre $\left(\mathrm{SO}_{2}\right)$, provenientes 
da queima de seus elementos. Esse gases então, são responsáveis pelas alterações climáticas que podem gerar aquecimento global como também, entre outras coisas propiciar a formação de chuva ácida.

Vale lembrar que, segundo o laboratório de Química Ambiental da Universidade de São Paulo (USP), o excesso de dióxido de carbono e enxofre em contato com a água da chuva forma ácido. Essa reação será responsável pela diminuição do PH da água de 7 para índices menores que 5,6 contaminando não só os lagos como os solos e toda biodiversidade do entorno, além de alterar a qualidade do ar afetando diretamente os seres humanos. ${ }^{5}$

A queima do carvão libera não só os gases de efeito estufa, mas também, mercúrio e partículas radioativas. Estes, associados aos outros elementos geram consequências alarmantes como relata Tyller Miller,

A cada ano, somente nos Estados Unidos, os poluentes do ar provenientes do carvão matam milhares de pessoas prematuramente (as estimativas variam de 65 mil a 200 mil), causam pelo menos 50 mil casos de doenças respiratórias e acarretam alguns bilhões de dólares de prejuízos a propriedades. Muitas pessoas desconhecem o fato de que a queima de carvão é responsável por um quarto da poluição atmosférica por mercúrio nos Estados Unidos e de que ela libera muito mais partículas radioativas no ar que as usinas nucleares em operação normal. (MILLER, 2013.p. 337)

Bom lembrar que, os gases de efeito estufa, permitem que a luz solar passe pela troposfera atingindo a superfície. Neste momento, esta última, absorve parte desse calor e devolve a outra parte para troposfera como raio infravermelho. Após essa absorção e reflexão, uma parte desses raios são enviados para o espaço, mas, a outra parte é ricocheteada pelos gases mencionados e enviados à troposfera. Tal fenômeno gera um aquecimento mútuo, ou seja, aumenta a temperatura da troposfera e da superfície terrestre. (MILLER, 2013)

A elevação dos gases de efeito estufa, principalmente $\mathrm{CO}_{2}$, tendem a piorar se as atitudes não se modificarem, pois o aumento da temperatura da troposfera acelera o derretimento das geleiras do ártico, por exemplo. Ao mesmo tempo, há um aumento do nível da água, que contribui ainda mais para o processo de derretimento.

5 Disponível em: www.usp.br/qambiental. 
Poderia ser questionado qual o liame entre o comentado efeito estufa e o derretimento das geleiras. Tal situação poderia atingir o subsolo congelante e liberar os gases de efeito estufa ali armazenados, corroborando com o aquecimento do planeta. (MILLER Jr, 2013)

No Painel Internacional de Mudanças Climáticas, ficou claro que uma boa parte da elevação da temperatura do Planeta advém das atividades antrópicas, como, por exemplo, a utilização de combustíveis fósseis para gerar energia, além do desmatamento das matas, o incentivo à agropecuária e plantações agrícolas. (SCHINDLER. Disponível em:http://www.fbds.org.br/ IMG/pdf/doc-76.pdf.)

Nesse caminho, é possível compreender que o avanço tecnológico, aliado à cobiça humana, objetivando produção e consumo em alta escala, ajuda a comprometer cada vez mais o capital natural do Planeta.

O Protocolo de Kyoto em 1997 vem sendo ponto importante na redução dos gases de efeito estufa, pois no supramencionado ano foi celebrado um acordo de redução de emissões de gases de efeito estufa pelos países, principalmente os desenvolvidos. Nesse caminho os Estados se comprometeram a diminuir suas emissões em torno de $5 \%$ até 2012, o que indica uma boa atitude, pois mesmo que muitos não os tenham atingido, esforços estão sendo feitos nesse sentido.

O Brasil, por exemplo, não conseguiu atingir a meta estabelecida, que era aproximadamente $39 \%$ das emissões. Contudo prevê, para os próximos anos, até 2020 que o objetivo seja alcançado.

Assim, o protocolo busca instituir uma política energética mais limpa que a atual. Para tanto, é necessário empenho dos países, no sentido de implantar políticas energéticas por fontes de energias renováveis, menos poluentes que a energia oriunda de combustíveis fósseis, como se observa da leitura do artigo segundo do referido documento ${ }^{6}$.

\section{${ }^{6}$ ARTIGO 2 ${ }^{\circ}$}

1. Cada Parte incluída no Anexo I, ao cumprir seus compromissos quantificados de limitação e redução de emissões assumidos sob o Artigo 3, a fim de promover o desenvolvimento sustentável, deve:

(a) Implementar e/ou aprimorar políticas e medidas de acordo com suas circunstâncias nacionais, tais como:

$\mathrm{O}$ aumento da eficiência energética em setores relevantes da economia nacional;

A proteção e o aumento de sumidouros e reservatórios de gases de efeito estufa não controlados pelo Protocolo de Montreal, levando em conta seus compromissos assumidos em acordos internacionais relevantes sobre o meio ambiente, a promoção de práticas sustentáveis de manejo florestal, florestamento e reflorestamento;

A promoção de formas sustentáveis de agricultura à luz das considerações sobre a mudança do clima;

A pesquisa, a promoção, o desenvolvimento e o aumento do uso de formas novas e renováveis de 
Assim sendo, embora, o carvão seja um dos recursos com maiores reservas a longo prazo e um dos recursos com maior potencial de geração de energia a baixo custo, é um dos maiores poluidores do meio ambiente, pois, desde a sua extração até sua combustão, ocorre afetação de toda a biodiversidade local e transfronteiriça.

Prova disso, é o resultado da extração mineral do carvão em Santa Catarina na década de setenta. O passivo ambiental deixado corresponde ao comprometimento de $2 / 3$ da malha hidrográfica da região. O PH da água, alcançou índices de 2 e 3 unidades, sendo importante frisar que o normal é acima de 5,6, abaixo disso, a acidez é considerável. (VAZ, 2003)

Tal estado negativo da água comprometeu a atividade pesqueira, uma vez que a água se tornou imprópria para a sobrevivência dos peixes. Isto sem falar especificamente na disposição dos rejeitos, feita de forma descomprometida com o meio ambiente. Contaminando além da água, o ar e solo, de toda a região e o seu entorno. (VAZ, 2003).

Considerando, o impacto ambiental nos moldes da resolução no1 do CONAMA de $1986^{7}$ é possível perceber quão grande foi o impacto ambiental na região de Criciúma.

\section{COMPETÊNCIA, RESPONSABILIDADE CIVIL E PROTEÇÃO AMBIENTAL}

Como espargido, a proteção ambiental nas constituições brasileiras anteriores a 1988 não era destacada diretamente. Nenhuma se referiu à

\footnotetext{
energia, de tecnologias de seqüestro de dióxido de carbono e de tecnologias ambientalmente seguras, que sejam avançadas e inovadoras;

A redução gradual ou eliminação de imperfeições de mercado, de incentivos fiscais, de isenções tributárias e tarifárias e de subsídios para todos os setores emissores de gases de efeito estufa que sejam contrários ao objetivo da Convenção e aplicação de instrumentos de mercado;

$\mathrm{O}$ estímulo a reformas adequadas em setores relevantes, visando a promoção de políticas e medidas que limitem ou reduzam emissões de gases de efeito estufa não controlados pelo Protocolo de Montreal;

Medidas para limitar e/ou reduzir as emissões de gases de efeito estufa não controlados pelo Protocolo de Montreal no setor de transportes;

A limitação e/ou redução de emissões de metano por meio de sua recuperação e utilização no tratamento de resíduos, bem como na produção, no transporte e na distribuição de energia;

7 qualquer alteração das propriedades físicas, químicas e biológicas do meio ambiente, causada por qualquer forma de matéria ou energia resultante das atividades humanas que, direta ou indiretamente, afetam:

I - a saúde, a segurança e o bem-estar da população;

II - as atividades sociais e econômicas;

III - a biota;

IV - as condições estéticas e sanitárias do meio ambiente;

V - a qualidade dos recursos ambientais.(BRASIL, CONAMA, 1986).
} 
utilização, degradação ou proteção jurídica ambiental de modo integral. Essa carência foi suprida com a Constituição da República de 1988, que reservou um capítulo específico para o meio ambiente.

O primeiro e único artigo deste capítulo, é o 225 que trata de estabelecer direitos e deveres referentes ao meio ambiente, como se percebe da leitura do caput $^{8}$.

Na primeira perspectiva, há o reconhecimento que todas as pessoas, indiscriminadamente, sem influência de raça, cor, sexo, religião e ou nacionalidade, têm a prerrogativa de usufruir de um ambiente ecologicamente equilibrado, pois este interferirá na qualidade de vida de cada um.

Na segunda perspectiva, impõe-se, um dever conjunto da sociedade e do poder público de defender e preservar o meio ambiente para todas as gerações atuais e futuras.

Percebe-se com isso, uma visão global do meio ambiente, diferentemente do que ocorria anteriormente, pois as constituições pretéritas, se referiam à uma proteção fragmentada, como demonstra Norma Sueli Padilha:

Nossas cartas constitucionais sempre se referiram a alguns elementos integrantes do meio ambiente, como, por exemplo, à água, as florestas, os minérios, a caça e a pesca, mas tal referência era dissociada de uma ideia holística e integrada, e demonstrava muito mais uma preocupação referida ao sistema de apropriação e utilização econômica de tais recursos naturais ou apenas ao regime de competências legislativas entre os entes da federação. (PADILHA, 2010. P.156)

De tal sorte que a nova constituição buscou a proteção do equilíbrio ambiental frente às ações humanas, maiores causadoras da degradação ambiental. Significa dizer, o desenvolvimento deve estar alinhado com a proteção ambiental. Como se percebe da leitura do art. 170 da CR/889.

O contexto da proteção ambiental no mundo, também não ocorreu de uma hora para outra. Contudo, trouxe um histórico de acontecimentos que

\footnotetext{
${ }^{8}$ Art. 225. Todos têm direito ao meio ambiente ecologicamente equilibrado, bem de uso comum do povo e essencial à sadia qualidade de vida, impondo-se ao Poder Público e à coletividade o dever de defendê-lo e preservá- lo para as presentes e futuras gerações. (BRASIL, 1988)

9 Art. 170. A ordem econômica, fundada na valorização do trabalho humano e na livre iniciativa, tem por fim assegurar a todos existência digna, conforme os ditames da justiça social, observados os seguintes princípios:

VI - defesa do meio ambiente, inclusive mediante tratamento diferenciado conforme o impacto ambiental dos produtos e serviços e de seus processos de elaboração e prestação (BRASIL, 1988).
} 
marcaram o mundo, não só pela degradação ambiental, mas pelo número de mortes de pessoas e animais.

Como exemplo, podem-se citar as duas Grandes Guerras Mundiais, a contaminação por mercúrio, jogado ao mar pela Fábrica Minamata no Japão e a utilização de pesticidas, nos Estados Unidos na década de 60. Tais desastres causaram a morte de várias espécies dentre elas a humana, o que chamou atenção para as questões ambientais. (COSTA, 2010).

Foi então, com a Conferência Das Nações Unidas Sobre Meio Ambiente Humano em 1972 que as questões ambientais se tornaram o foco da discussão na seara internacional. A princípio, a proposta era orientar os países em desenvolvimento a não cometerem o mesmo desenfreado crescimento econômico dos países desenvolvidos. Consideraram para tanto, as experiências negativas vivenciadas.

Nas prévias de Estocolmo, o Brasil foi um forte opositor à diminuição do desenvolvimento. Tanto que convidou as empresas poluidoras a participarem do progresso do Brasil. No início o país não era visto com bons olhos.

Mas, com o passar das discussões, as propostas brasileiras representadas pelo Ministro Costa Cavalcanti foram tomando corpo e o Brasil passou a ser o líder da bancada dos países em desenvolvimento. (RIBEIRO, 2006)

Uma das propostas levantadas, segundo o autor supracitado, foi sobre o ônus do controle ambiental e da despoluição, de modo que estes caberiam aos países desenvolvidos por causarem maior dano ao meio ambiente.

Esta recomendação feita muito se relaciona com o princípio da Responsabilidade Comum mas Diferenciada, acatado pela conferência posteriormente. Conforme expõe Chris Wold (2003), este princípio busca um "compartilhamento de responsabilidades internacionais para a solução de problemas ambientais globais que levem em consideração a realidade socioeconômica dos diferentes Estados".

Em junho de 1972 a Conferência ocorreu propondo 26 princípios que instigavam a proteção ambiental. Embora não tivesse criado nada de concreto para responsabilização dos países foi muito importante, pois por meio dela, segundo Wold, "propiciou-se a primeira moldura conceitual abrangente para formulação e implementação estruturada do Direito Internacional do meio Ambiente".

Outro encontro importante para a história da proteção ambiental foi em 1992 com a Cúpula da Terra sobre Meio Ambiente e Desenvolvimento. Nesta 
conferência ocorreu a ratificação da Conferência de Estocolmo e passou-se ao centro das discussões o desenvolvimento sustentável.

Esse encontro foi uma forma de buscar metas mais definidas quanto aos problemas ambientais globais, conforme expõe Norma Sueli:

Os debates se centraram na necessidade de se firmarem regras mais claras e objetivas para o enfrentamento da problemática ambiental internacional e de se desenvolverem estratégias para um novo modelo de desenvolvimento. Os documentos firmados na Rio/92 passaram, a partir de então, a representar papel significativo no crescimento e evolução da normatividade ambiental global. (PADILHA, 2010. P. 61).

Tanto a Conferência de 1972 quanto a de 1992, são importantes marcos morais de comportamento, pois embora não imponham nenhuma obrigatoriedade, serviram como guia para a modificação de alguns ordenamentos jurídicos que introduziram tais preceitos internamente.

Outras conferências mundiais protecionistas ocorreram a partir de então, dentre elas o já mencionado Protocolo de Kyoto em 1997, que tratava da redução dos gases de efeito estufa, a Rio +10 em 2002 sobre Desenvolvimento Sustentável, a Conferência sobre Mudanças Climáticas em Copenhague em 2009, propondo novos objetivos para a redução de gases de efeito estufa.

Como se percebe até agora, o meio ambiente deve ser protegido não só por questões físicas e estéticas, mas também, em face da degradação ambiental que ameaça a vida das espécies e de todo ecossistema. Além disso, seu valor é tamanho ao ponto de ser considerado um direito fundamental transindividual. Tal perspectiva foi demonstrada pelo STF no julgamento de Medida Cautelar na Ação Direta de Inconstitucionalidade 3540 de 2005. ${ }^{10}$

Entende-se aqui, como meio ambiente, o conceito de Beatriz Souza Costa "o conjunto de elementos naturais e artificiais partilhados com seres humanos e não humanos, necessários ao desenvolvimento e sobrevivência dessas espécies de forma harmônica e solidária".

\footnotetext{
${ }^{10}$ Todos têm direito ao meio ambiente ecologicamente equilibrado. Trata-se de um típico direito de terceira geração (ou de novíssima dimensão), que assiste a todo o gênero humano (RTJ 158/205206). Incumbe, ao Estado e à própria coletividade, a especial obrigação de defender e preservar, em benefício das presentes e futuras gerações, esse direito de titularidade coletiva e de caráter transindividual (RTJ 164/158-161). O adimplemento desse encargo, que é irrenunciável, representa a garantia de que não se instaurarão, no seio da coletividade, os graves conflitos intergeneracionais marcados pelo desrespeito ao dever de solidariedade, que a todos se impõe, na proteção desse bem essencial de uso comum das pessoas em geral. (STF, 2005).
} 
Assim sendo, cabe ao poder público e a sociedade proteger esse conjunto de elementos, pois são bens de uso comum do povo. Nessa seara, diferentemente daquela defendida pelo art. 99, I da lei 10.406/2002, inclui-se a função social e ambiental da propriedade como fundamento da gestão do meio ambiente. (MACHADO, 2007. P.122)

Assim, deve ser levado em conta, que o poder público não é proprietário de nenhum bem ambiental, mas gestor, como bem explica Paulo Afonso Leme Machado

O poder público passa a figura não como proprietário de bens ambientais... mas como um gestor ou gerente que administra bens que não são dele e, por isso, deve explicar convincentemente sua gestão. A aceitação dessa concepção jurídica vai conduzir o Poder Público a melhor informar, a alargar a participação da sociedade civil na gestão dos bens ambientais e a ter que prestar contas sobre a utilização dos bens "de uso comum do povo", concretizando um "Estado Democrático e Ecológico de Direito"(MACHADO,2007.P. 122)

Vale ressaltar também que o Poder Público é responsável pela proteção ambiental, não apenas na esfera executiva, mas também por meio do legislativo e judiciário.

Nos dizeres de Jose Afonso da Silva:

Poder Público é a expressão genérica que se refere a todas as entidades territoriais públicas, pois uma das características do estado Federal, como o nosso, consiste precisamente em distribuir o poder público por todas as entidades autônomas que o compõe, para que cada qual o exerça nos limites das competências que lhe foram outorgadas pela Constituição. (SILVA, 2009)

Portanto dentro do federalismo brasileiro, compete à União elaborar e executar planos nacionais e regionais de ordenação do território e de desenvolvimento econômico e social, assim como, explorar, diretamente ou mediante autorização, concessão ou permissão os serviços e instalações de energia elétrica e o aproveitamento energético dos cursos de água, em articulação com os Estados onde se situam os potenciais hidroenergéticos; Art. 21 IX e XII da CR/88.

Além disso, compete privativamente à União, legislar sobre água e energia conforme art. 22, IV da carta constitucional. 
A Constituição também determina em seu art. 23 como competência comum entre todos os entes federados a proteção do meio ambiente e o combate à poluição em qualquer de suas formas, assim como preservação das florestas, da fauna e da flora. Além, de ser responsável pelo registro, acompanhamento e fiscalização de todas as concessões de direitos e pesquisas e exploração dos recursos hídricos e minerais em seus respectivos territórios.

Aos Estados e Municípios, entretanto, caberão também a possibilidade de suplementar a legislação federal e Estadual no que couber, conforme art. 24, VI, VII, VIII e seu parágrafo $2^{\circ}$, art. 30 VIII, Art. 182 e art. 30 II. Embora exista um vasta discussão sobre a competência supletiva municipal.

Seguindo o raciocínio de Jose Afonso da Silva, conclui-se que, se o Município tem competência para promover o adequado ordenamento territorial, por meio do uso e parcelamento e ocupação do solo urbano. Do mesmo modo, tem competência para estabelecer a política de desenvolvimento urbano.

Bom lembrar que, dentro as competências municipais, ainda se encontra a responsabilidade pela proteção do patrimônio histórico cultural local e a proteção do meio ambiente.

Portanto, embora haja discussão sobre a competência complementar dos municípios, neste trabalho será reconhecido tal prerrogativa, em consonância, com os fundamentos supracitados.

Demonstrado a importância da proteção ambiental na Constituição brasileira e nas Convenções internacionais, que contribuíram para que a questão ambiental tomasse corpo. Demonstrado também, a competência de cada ente federado sobre esse bem de uso comum do povo, resta analisar então a questão da responsabilidade civil.

A Responsabilidade Civil do Estado pelo dano ambiental, é objetiva, assim já delineia o art. $225 \S 3^{\circ}$ da Constituição da República, quando impõe que as condutas e atividades consideradas lesivas ao meio ambiente sujeitarão os infratores, pessoas físicas ou jurídicas, a sanções penais e administrativas, independentemente da obrigação de reparar os danos causados.

Logo, percebe-se que não há necessidade de demonstrar a culpa, bastando apenas a existência de três elementos, quais sejam, conduta, dano e o nexo de causalidade entre o dano e a conduta. Em outras palavras,

Nessa teoria a ideia de culpa é substituída pela de nexo de causalidade entre o funcionamento do serviço público e o prejuízo sofrido pelo administrado. É indiferente que o serviço público tenha funcionado bem ou mal, de forma 
regular ou irregular. Constituem pressupostos da responsabilidade objetiva do Estado: a) que seja praticado um ato lícito ou ilícito, por agente público; b) que esse ato cause dano específico (porque atinge apenas um ou alguns membros da coletividade) e anormal (porque supera os inconvenientes normais da vida em sociedade, decorrentes da atuação estatal); c) que haja um nexo de causalidade entre o ato do agente público e o dano. (DI PIETRO, 2012)

Esse tipo de responsabilidade é acolhida também no artigo 37 parágrafo $6^{\circ} \mathrm{da} \mathrm{CR} / 88$, quando estabelece que as "pessoas jurídicas de direito público e as de direito privado que prestam serviços públicos, responderão pelos danos que seus agentes, nessa qualidade, causarem a terceiros, assegurando o direito de regresso contra o responsável do dano, nos casos de dolo ou culpa". Essa perspectiva também se encontra no Código Civil de $2002^{11}$.

Já a responsabilidade por omissão ou subjetiva, se fundamenta na teoria da culpa do serviço público, que considera três possibilidades de responsabilização do Estado quanto à prestação de serviço. Primeira, quando o serviço público não funciona. Segunda, quando o serviço funciona atrasado e terceira, quando funciona mal. Nos casos de não funcionamento do serviço ou funcionamento tardio, o mais acertado é reconhecer que ocorreu uma omissão danosa. (PIETRO, 2012. P. 709)

Os danos causados por inércia do Estado, geralmente não são causados por agentes públicos, mas por terceiros ou por fatos naturais. Ocorre que a responsabilização se justifica porque o ente público deveria ter sido vigilante e não o foi.

Vale lembrar que, a responsabilidade não surge de qualquer omissão do Estado, mas quando existe um dever e a possibilidade de agir.

Na primeira obrigação deve ser considerado o principio da legalidade, que determina que a administração só pode fazer ou deixar de fazer alguma coisa em virtude de lei. Portanto, se tinha o dever de agir e não agiu configura a omissão.

Na segunda, não basta a vontade, o animus de agir do Estado, é necessária a viabilidade, a oportunidade do agir para que prevenção do dano aconteça. Logo se existiu a chance de prevenir o dano e o Estado não a aproveitou, ele deverá ser responsabilizado.

\footnotetext{
${ }^{11}$ Art. 43. As pessoas jurídicas de direito público interno são civilmente responsáveis por atos dos seus agentes que nessa qualidade causem danos a terceiros, ressalvado direito regressivo contra os causadores do dano, se houver, por parte destes, culpa ou dolo.
} 
Nesse sentido, se o Estado não age quando deveria e nada faz para evitar a lesão quando tinha condições pra fazê-lo, ocorrerá a presunção de culpa do poder público. Caberá a este, no entanto, demonstrar que agiu conforme os ditames legais e que não agiu por falta de alternativa, única opção de ser inocentado.

Como já demonstrado, existe todo um aparato constitucional e infraconstitucional que impõe ao poder público o dever de proteger, controlar, reparar e fiscalizar o meio ambiente.

Junta-se, a esse aparato protetivo a lei 6.938 de 1981 que institui a Política Nacional do Meio Ambiente, com objetivo não só de preservação do meio ambiente como também de melhoria e recuperação da qualidade ambiental propícia à vida. Do mesmo modo, procurou-se assegurar no Brasil condições ao desenvolvimento sócio-econômico, aos interesses da segurança nacional e à proteção da dignidade da vida humana.

Ressalta-se que, para estes objetivos serem alcançados, a ação governamental na manutenção do equilíbrio ecológico, deve considerar o meio ambiente como um patrimônio público a ser necessariamente assegurado e protegido, visando o uso coletivo.

Além disso, a Política Nacional do Meio Ambiente deve utilizar do planejamento e da fiscalização, quando a matéria se referir ao uso dos recursos ambientais. (Lei.6.938/81, Art. 2)

Nessa oportunidade, ocorreu a criação do Sistema Nacional do Meio Ambiente (SISNAMA), composto pelo Conselho Nacional do meio Ambiente (CONAMA), órgão consultivo e deliberativo, e pelo o Instituto Brasileiro do Meio Ambiente e dos Recursos Naturais Renováveis (IBAMA), para exercer o controle e fiscalização dos empreendimentos que possam afetar o meio ambiente.

Prova dessa atuação é o artigo $10^{\circ}$ dessa lei que exige licenciamento ambiental para os empreendimentos que possam afetar o meio ambiente, atribuindo competência ao CONAMA e ao IBAMA quanto às normas e fiscalização ${ }^{12}$.

\footnotetext{
${ }^{12}$ Art. 10. A construção, instalação, ampliação e funcionamento de estabelecimentos e atividades utilizadores de recursos ambientais, efetiva ou potencialmente poluidores ou capazes, sob qualquer forma, de causar degradação ambiental dependerão de prévio licenciamento ambiental.

Art. 11. Compete ao IBAMA propor ao CONAMA normas e padrões para implantação, acompanhamento e fiscalização do licenciamento previsto no artigo anterior, além das que forem oriundas do próprio CONAMA.

$\S 2^{\circ}$ - Inclui-se na competência da fiscalização e controle a análise de projetos de entidades, públicas ou privadas, objetivando a preservação ou a recuperação de recursos ambientais, afetados por processos de exploração predatórios ou poluidores. (BRASIL, lei 6.938/81)
} 
Antes dessa legislação, no entanto, já existia o Decreto Lei 227 de 1967 que instituía no ordenamento jurídico o Código de Minas. Por ele, a União tinha competência para administrar os recursos minerais, a indústria de produção mineral assim como distribuição, consumo e comércio de produtos minerais.

Nesse caminho, o órgão competente para execução e fiscalização da legislação seria o Departamento Nacional de Produção Mineral (DNPM) conforme art. 88 do referido código.

Percebe-se ainda, que à época, mesmo antes de Estocolmo, o empreendedor deveria ter cuidado com os bens ambientais, caso contrário seria penalizado podendo até perder o título de concessão ${ }^{13}$.

Assim, quando ocorreu a degradação ambiental na região de Santa Catarina, que teve início na década de 70, pretérita à Constituição Ambiental de 1988, já existia mecanismos de proteção ambiental à disposição do poder público, não eximindo assim sua responsabilidade.

\section{INTERVENÇÃO JUDICIAL COMO INSTRUMENTO DE EFETIVIDADE DA PROTEÇÃOAMBIENTAL}

O Poder Judiciário brasileiro, Poder Público, por ser constitucionalmente reconhecido como um dos poderes da União, tem o dever de proteger o meio ambiente assim como o legislativo e o executivo.

Na mesma linha de raciocínio, sendo o Estado um defensor dos direitos fundamentais, e considerando o meio ambiente um direito fundamental implícito na constituição e interligado ao direito à vida, todos tem o direito de viver em um ambiente ecologicamente equilibrado. Todos os poderes estatais tem a incumbência de proteger esse meio ambiente. (SARLET, 2012)

No mesmo sentido Tiago Fensterseifer,

\footnotetext{
${ }^{13}$ Art. 47. Ficará obrigado o titular da concessão, além das condições gerais que constam deste Código, ainda, às seguintes, sob pena de sanções previstas no Capítulo V

VIII - Responder pelos danos e prejuízos a terceiros, que resultarem, direta ou indiretamente, da lavra;

IX - Promover a segurança e a salubridade das habitações existentes no local;

$\mathrm{X}$ - Evitar o extravio das águas e drenar as que possam ocasionar danos e prejuízos aos vizinhos;

XI - Evitar poluição do Art., ou da água, que possa resultar dos trabalhos de mineração;

Art. 63. O não cumprimento das obrigações decorrentes das autorizações de pesquisa, das permissões de lavra garimpeira, das concessões de lavra e do licenciamento implica, dependendo da infração, em:

I - advertência;

II - multa; e

III - caducidade do título.
} 
Assim em maior ou menor medida, todos os poderes estatais (Executivo, legislativo e Judiciário), estão constitucionalmente obrigados, na forma de deveres de proteção e promoção ambiental, a atuar, no âmbito da sua esfera constitucional de competências, sempre no sentido de obter a maior eficácia e efetividade possível dos direitos e deveres fundamentais. (SARLET, 2012)

Logo, se o próprio Estado por meio do Poder Legislativo e do Poder Executivo, como também os seus órgãos, faltar com a proteção ambiental, estará incorrendo em inconstitucionalidade, cabendo ao Poder Judiciário intervir, visando o bem maior, que é o equilíbrio ambiental.

Ingo Sarlet citando Medauar esclarece,

Cabe ao judiciário apreciar o cumprimento, por parte do legislativo ou por parte do Executivo, das diretrizes constitucionais ou legais relativas à proteção ambiental, para que tornem efetivas e não sejam desrespeitadas e ignoradas. Resta claro, assim, que no caso das omissões do Executivo, há muitas consideradas pelo judiciário na esfera da Responsabilidade Civil, hão de ser apreciadas em matéria de defesa do meio ambiente, para autoridades sejam obrigadas a adotar as medidas permanentes, com fundamento sobre tudo na Constituição Federal. (SARLET, 2012)

Reconhecer a importância da jurisprudência no contexto da proteção ambiental se faz necessário, pois, além de formar precedentes, obriga a adoção de medidas que contribuirão com as políticas públicas protetivas.

Nesse sentido, o judiciário de vários países vem incluindo a proteção ambiental em seus julgados, dando maior peso às questões ambientais frente ao viés econômico.

É o que demonstra o documento do Programa das Nações Unidas para Meio Ambiente (PNUMA) numa análise jurisprudencial da América Latina

No entanto, a jurisprudência latino-americana vem acompanhando as mudanças dos problemas ambientais e comportando-se à altura dos novos tempos. Com efeito, ao início hesitante, tímida mesmo, mais recentemente as decisões judiciais revelam alto grau de conhecimentos e preocupações ambientais.

A Argentina é um bom exemplo disto. Não mais do que dez anos, poucas eram as decisões dos Tribunais argentinos sobre processos ambientais. Todavia, em tempos mais recentes, há julgamentos de elevado teôr científico e sobre variados aspectos do Direito Ambiental. Principalmente na área da reparação civil por danos ambientais. 
O acórdão, objeto desse trabalho, é um exemplo de efetividade do poder judiciário para a proteção ambiental, pois, no Brasil foi a primeira vez que ocorreu a condenação criminal de pessoas jurídicas, assim como, a condenação da própria União.

A ação Judicial pode ser vista como instrumento de atuação política, posto que ao julgar Ações Populares e Ações Civis, reconhece uma democracia participativa.

Nessa esteira, quando o Poder Público não age quando deveria, os meios que a coletividade tem para proteger o bem ambiental consistem no ajuizamento de tais instrumentos fiscalizatórios.

Do mesmo modo, o poder Judiciário, fazendo valer o papel de protetor do meio ambiente, exteriorização do próprio Poder conferido pelo art. 225 da constituição, torna-se instrumento da política estatal. Logo, não lhe cabe a inércia, mas a responsabilidade de efetivar a proteção ambiental por meio da sua decisão.

Ingo Sarlet considera essa atuação do poder Judiciário no cumprimento da tutela ambiental associado a políticas do Estado, como governança ambiental.

Bom lembrar que, no caso de Criciúma o juiz criou um grupo de assessoramento técnico especializado para dirimir as dúvidas, evitando morosidade na execução dos projetos e conferindo efetividade à sentença.

Tal atitude do magistrado resultou em uma maior fiscalização pelo poder público, pois, os órgãos especializados deveriam acompanhar o projeto de recuperação para conceder licenças, viabilizando a implementação dos mesmos. Além disso, deu maior agilidade no processo de recuperação da área degradada.

Necessário frisar que prova do comentário acima é o relatório da empresa mineradora, Coque Mineradora, demonstrando os passos de todo o processo de recuperação e as expectativas futuras.

A área foi recuperada segundo os Critérios para recuperação e reabilitação de áreas degradadas pelo carvão - Revisão 03 e agora será dado continuação aos monitoramentos ambientais propostos no PRAD, e a empresa está aguardando a emissão da Licença Ambiental de Operação pela FATMA. Após a finalização das obras de recuperação já se pode notar a melhoria significativa da qualidade dos recursos hídricos superficiais. Com os monitoramentos poderemos avaliar o retorno da fauna ao local, o desenvolvimento das espécies arbóreas e arbustivas na área de preservação permanente, e possíveis correções que deverão ser realizadas quanto a reforço de adubação, reforço de vegetação, replantio de mudas e correção de processos erosivos. (COQUE CATARINENSE LTDA, 2011) 
A fase de cumprimento da sentença, da ação civil do Estado de Santa Catarina, é que chama atenção e pode ser utilizada como exemplo para muitos tribunais. Segundo a análise do PNUMA, o juiz agiu de forma que a degradação ambiental fosse minimizada, para isso tomou várias providências, como se observa,

A primeira medida tomada pelo Juiz Federal Marcelo Cardoso da Silva, foi reunir todos os interessados, em uma audiencia puìblica, para discutir como seria feita a execuc'aPo. $\mathrm{O}$ ato foi oportuno, pois deu a todos a ciencia de suas responsabilidades e que o objetivo maior dependia de esforc'os conjugados. Foi identificada cada aìrea degradada, ou seja, aquela onde ocorreu, por ac'abo antroìpica, perda de algumas de suas caracteriìsticas fiìsicas, quiìmicas e bioìticas, suficientes para prejudicar a estabilidade do ecossistema e afetar negativamente seu potencial soìcioeconomico. Em um terceiro passo, o magistrado determinou que cada condenado apresentasse um "Projeto de reabilitac'aPo de aìreas degradadas (PRAD)" pela minerac'aPo. Cada Projeto de reabilitac'aPo eì submetido ao exame do oìrgaPo ambiental do Estado de Santa Catarina e deve obter uma licenc'a ambiental para poder ser aplicado. (PNUMA, 2007)

Assim, as decisões judiciais dessa ação civil pública, proposta pelo Ministério Público Federal, cumpriram o encargo atribuído pela Constituição da República no tocante a proteção ambiental.

Portanto percebe-se que a intervenção judicial na seara ambiental é de suma importância, mas para ser efetiva, além do conhecimento da matéria para dar mais sustância à decisão, é preciso interesse para que a decisão se concretize realmente e não só no papel.

\section{CONSIDERAÇOES FINAIS}

Com a evolução do homem e de suas atividades, a degradação ambiental vem aumentando. Com isso as consequências também. Nesse caminho, é preciso agir, para não ficar utilizando medidas compensatórias posteriormente.

A importância de se conhecer os aspectos científicos dos minerais não renováveis e sua implicação para a degradação ambiental se faz presente. Além do que, instiga à pesquisa de novas alternativas que ajudem na proteção ambiental. 
Como visto, embora abundante, ainda, o carvão continua sendo o vilão para as mudanças climáticas. Por ser um combustível fóssil, sua combustão libera dióxido de carbono para atmosfera, um dos gases mais potentes para gerar o efeito estufa.

O Estado de Santa Catarina sofreu no solo, no ar e nas águas o efeito do progresso, pela extração, industrialização do carvão. Hoje, está em pleno processo de reabilitação, mas, com as marcas deixadas pela degradação.

$\mathrm{O}$ acórdão muito bem as consequências ambientais advindas dessa extração, feita, sem qualquer rigor técnico do ponto de vista ambiental e foi imperioso na condenação da União pela falta de serviço.

Com o passar dos tempos, viu-se que a questão da proteção ambiental ganhou maior visibilidade no direito internacional a partir de Estocolmo, em 1972 e por meio da Cúpula da Terra, em 1992, mas foi preciso que grandes eventos negativos ocorressem, para que a atenção da comunidade internacional se voltasse para este ponto.

A degradação na Cidade de Criciúma pode ser concebida, como exemplo nacional da importância de se preservar o meio ambiente e de quão participativa deve ser a sociedade para não permitir que tragédias como essa se repitam.

Ficou demonstrado que o Estado, no caso a União, deveria responder solidariamente, com fundamento na responsabilidade civil por omissão. À época, já existia legislação protetiva, como o código de minas, vigente desde 1967. Frise-se, antes da atividade extrativista acontecer.

Após esse período, veio a Lei 1.413 de 1975, que já tratava da poluição causada pelas indústrias. Contudo, a União continuou sem fiscalizar as atividades extrativistas.

Do mesmo modo, em 1981 com a Política Nacional do Meio ambiente e o advento da constituição 1988, oportunidades excepcionais para motivar tomada de atitude, no ente federativo a inércia imperava.

Restou assim, comprovada a ilegalidade, pelo descumprimento do dever de agir. Sem, no entanto, ocorrer justificativa plausível que indicasse a impossibilidade de tal conduta. Até porque, à época já existiam órgãos competentes para fiscalização.

Continuando o raciocínio, cabe ao Poder Público gerir os bens ambientais, administrá-los da melhor maneira. Esse é o intuito da Constituição da República de 1988.

Nesse sentido, compete ao poder judiciário, investido no Poder Público Estatal, proteger o meio ambiente. Para isso, o juiz deve ser conhecedor das 
questões ambientais, problemas e soluções. Deve visar eficiência e efetividade na proteção do meio ambiente, sendo um instrumento da Política Nacional do Meio Ambiente e principalmente da Constituição.

Nessa perspectiva, as intervenções judiciais com tutela ambiental, passarão a ser precedentes para outros julgados e imporão de certa forma condutas menos ofensivas e mais conscienciosas ao meio ambiente.

\section{REFERÊNCIAS}

BENJAMIM, Antônio Herman. Responsabilidade Civil pelo Dano Ambiental. Revista de Direito ambiental RDA 9/5. Jan-mar.1998. p.75 a 136.

BRASIL, Decreto-Lei No 227, de 28 de fevereiro de 1967. Dá nova redação ao Decreto-lei $n^{0}$ 1985, de 29 de janeiro de 1940 (Código de Minas). Disponível em: http://www.planalto.gov.br/ccivil_03/decreto-lei/ del0227.htm. Acesso 20/05/2014

BRASIL, Decreto-Lei $\mathrm{n}^{\circ} 1.413$, de 14 de agosto de 1975 . Dispõe sobre o controle da poluição do meio ambiente provocada por atividades industriais. Disponível em: http://www2.camara.leg.br/legin/fed/declei/19701979/decreto-lei-1413-14-agosto-1975-378171-norma-pe.html . Acesso em: $15 / 05 / 2014$

BRASIL, Decreto ${ }^{\circ} 76.389$, de 3 de outubro de 1975 . Dispõe sobre as medidas de prevenção e controle da poluição industrial, de que trata o Decreto-Lei $n^{0} 1.413$, de 14 de agosto de 1975, e dá outras providências. Disponível em: http://www2.camara.leg.br/legin/fed/decret/ 1970-1979/decreto-76389-3-outubro-1975-424990-publicacaooriginal-1pe.html. Acesso em: 15/05/2014

BRASIL, Decreto $n^{\circ} 85.206$, d 25 de setembro de 1980. Altera o artigo $8^{\circ}$ do Decreto $n^{0}$ 76.389, de 3 de outubro de 1975, que dispõe sobre as medidas de prevenção e controle da poluição industrial. Disponível em: http://www2.camara.leg.br/legin/fed/decret/1980-1987/decreto-85206-25setembro-1980-434622-publicacaooriginal-1-pe.html. Acesso em 20/05/2014.

BRASIL, Lei 6.938, de 31 de agosto de 1981. Dispõe sobre política nacional do Meio Ambiente, seus fins e mecanismos de formulação e 
aplicação, e dá outras providências. Disponível em: http://www.planalto. gov.br/ccivil_03/leis/16938.htm. Acesso em: 19/05/2014

BRASIL, Constituição da República Federativa do Brasil de 1988.

Disponível em: http://www.planalto.gov.br/ccivil_03/constituicao/ constituicaocompilado.htm. Acesso em 24/05/2014

BRASIL, Lei $\mathrm{n}^{\circ} 7.805$, de 18 de julho de 1989. Altera o Decreto-lei $\mathbf{n}^{\circ}$ 227, de 28 de fevereiro de 1967, cria o regime de permissão de lavra garimpeira, extingue o regime de matrícula, e dá outras providências. Disponível em: http://www.planalto.gov.br/ccivil_03/Leis/L7805.htm. Acesso em: 20/05/2014

BRASIL, Lei 10.406, de 10 de janeiro de 2002. Institui o Código Civil. Disponível em: http://www.planalto.gov.br/ccivil_03/leis/2002/110406.htm. Acesso 15/05/2014

COQUE CATARINENSE LTDA, mineração de carvão. Relatório de Monitoramento. Pinheirinho Alto, Proc. FATMA DIV. 490/CODAMCRI. Cumprimento de sentença no 2008.72.04.002970-5/SC. Vol. 04/ 2011. In: Portal da Ação Civil pública do Carvão. Disponível em: https://www.jfsc.jus.br/acpdocarvao/2011/Agosto-2011/Cocalit-relatorio-deandamento-de-recuperacao-ambiental/Cocalit-Pinheirinho-Alto-relatorio-deandamento-de-recuperacao-ambiental-relatorio-de-andamento-derecuperacao-ambiental.htm. Acesso em: 25/03/2014

COSTA, Beatriz Souza. Meio ambiente como direito à vida. O Lutador. Belo Horizonte, 2010. 128 p.

COSTA, Beatriz Souza. O gerenciamento econômico do minério de ferro como bem ambiental no direito constitucional brasileiro. Fiuza. Belo Horizonte, 2009. 205 p.

DI PIETRO, Maria Sylvia Zanella. Direito Administrativo. Atlas, 25ª São Paulo 2012. 932 p.

JURISPRUDÊNCIA AMBIENTAL na América Latina: recopilação e análise dos casos relevantes. http://www.pnuma.org/deramb/documentos/ 
jurisprudencia\%20ambiental/Brasil\%20-\%20Caso\%20Mineria\%20y\% 20Medio\%20Ambiente.pdf. Acesso em: 23/05/2014

MACHADO, Paulo Afonso Leme. Direito ambiental brasileiro. Malheiros 15․ São Paulo, 2007. 1110 p.

MARQUEZ, Dr. José Gonzáles. La responsabilidade por el daño ambiental en América Latina. In: PNUMA, Programa das Nações para Meio Ambiente. Disponível em: http://www.pnuma.org/deramb/documentos/ jurisprudencia\%20ambiental/Brasil\%20-\%20Caso\%20Mineria\%20y\%20 Medio\%20Ambiente.pdf. Acesso em: 25/03/2014

MILlER JR., G. Tyler. Ciência Ambiental. Cengage. São Paulo 2013. $501 \mathrm{p}$.

PADILHA, Norma Sueli. Fundamentos constitucionais do direito ambiental brasileiro. Campus. Rio de Janeiro, 2010. 451 p.

PNUMA, Programa das Nações Unidas. Recurso Especial $\mathbf{n}^{0}$ 647.493/ SC, segunda turma, relator Min. João Otávio Noronha. 2007. Disponível em: http://www.pnuma.org/deramb/documentos/jurisprudencia\% 20ambiental/Brasil\%20-\%20Caso\%20Mineria\%20y\%20Medio\%20 Ambiente.pdf

TEIXEIRA, Orci Paulino; MALLMANN, Natália. Responsabilidade Civil Ambiental: uma análise crítica sobre o nexo de causalidade e seus limites em casos de pluralidade de agentes poluidores. Disponível em: http://www.pucrs.br/edipucrs/XISalaoIC/Ciencias_Sociais_Aplicadas/Direito/ 83244-NATALIAMALLMANN.pdf acesso em 23/03/14

RIBEIRO, José Claudio Junqueira. Indicadores Ambientais. Belo Horizonte, 2006. 304 p.

SARLET, Ingo Wolfgang; FENSTERSEIFER, Tiago. Direito Constitucional ambiental. Revista dos Tribunais 2a. São Paulo, 2012. 286 p.

SCHINDLER, Walfredo. Coalizão empresas pelo clima. In: Fundação Brasileira para o desenvolvimento sustentável- FBD. Disponível em: http://www.fbds.org.br/IMG/pdf/doc-76.pdf. Acesso em 20/03/2014 
SILVA, José Afonso da. Direito Ambiental Constitucional. Malheiros $7^{\mathrm{a}}$. São Paulo, 2009. 351p.

STF, Supremo Tribunal Federal. Medida Cautelar em Ação Direta de Inconstitucionalidade. Relator, Min. Celso de Mello em 01/09/2005. In: Jurisprudências. Disponível em: http://www.stf.jus.br/portal/jurisprudencia/ listarJurisprudencia.asp?s $1=\% 28$ todos+tem+o+direito+ao+meio+ambiente+ ecologicamente+equilibrado\%29\&base=baseAcordaos\&url=http:// tinyurl.com/12ubve5. Acesso em: 19/03/2014

\section{UNIVERSIDADE DE SÃO PAULO (USP). Poluição atmosférica e} chuva ácida. In: Quer saber mais? Química Ambiental. Disponível em: http://www.usp.br/qambiental/chuva_acidafront.html. Acesso em: 25/03/ 2014

VAZ, Paulo Afonso Brum. Reparação do dano ambiental- caso concreto mineração em Santa Catarina e o meio ambiente. Conferência proferida no "Seminário de Direito Ambiental - Ano V. 2003.

http://www2.cjf.jus.br/ojs2/index.php/revcej/article/viewFile/563/743. Acesso em 23/03/2014

WOLD, Chris; SAMPAIO, José Adércio Leite; NARDY, Afrânio.

Princípios de Direito Ambiental. Del Rey. Belo Horizonte 2003. 284 p.

Artigo recebido em: 29/05/2014 Aprovado para publicação em: 05/12/2014

Como citar: COSTA, Beatriz Souza. SOUZA, Lívia Maria Cruz Gonçalves. A atuação do Poder Judiciário frente à responsabilidade civil do Estado, pela ineficiência de fiscalização, como instrumento de efetividade para se alcançar a proteção ambiental. Revista do Direito Público. Londrina, v.9, n.3, p.223-246, set./dez.2014. DOI: 10.5433/1980-511X.2014v9n3p223. 